\title{
Characterization of lytic human herpesvirus-8 gene expression in Kaposi sarcoma tumor tissue and its clinical correlates
}

\author{
Warren Phipps ${ }^{1,5^{*}}$, Jackson Orem ${ }^{6,7}$, Innocent Mutyaba ${ }^{6,7}$, James Ferrenberg ${ }^{2}$, Misty Saracino ${ }^{2}$, Meei-Li Huang ${ }^{2}$, \\ Jeff Vieira ${ }^{2}$, Anna Wald ${ }^{1,2,3,5}$, Larry Corey ${ }^{1,2,5}$, Corey Casper ${ }^{1,3,4,5}$ \\ From $12^{\text {th }}$ International Conference on Malignancies in AIDS and Other Acquired Immunodeficiencies \\ (ICMAOI)
}

Bethesda, MD, USA. 26-27 April, 2010

\section{Background}

Human herpesvirus 8 (HHV-8) replication is necessary for KS tumor growth and maintenance, and the detection of replicating $\mathrm{HHV}-8$ in the peripheral blood predicts the development of KS [1]. Quantities of HHV-8 lytic and latent mRNA vary in KS biopsy tissue $[2,3]$, suggesting that differences in lytic gene expression may be important in tumor pathogenesis and could have clinical significance. We evaluated lytic and latent mRNA transcripts in KS tumors from Ugandans with epidemic KS, and examined associations between HHV-8 gene expression in tumors, KS morphology, and systemic viral replication.

\section{Methods}

KS biopsy specimens were obtained from 13 treatmentnaive, HIV-positive Ugandans with histologically confirmed KS. Participants also collected oral swabs daily and plasma samples weekly over 4 weeks to quantify HHV-8 replication. HHV-8 mRNA gene transcripts, including 2 lytic genes (K8 and ORF50) and 1 latent gene (ORF73), and GAPDH were quantified in biopsy specimens using RT-PCR; total RNA was determined by optical density. Only specimens with total RNA $>10 \mathrm{ng}$ and GAPDH threshold cycle $(\mathrm{Ct})<35$ were included in the analysis. HHV-8 mRNA log copies were normalized to the total ng of RNA in samples.

\section{Results}

HHV-8 mRNA gene transcripts were detected in all $13 \mathrm{KS}$ biopsy samples. In all samples, the quantity of mRNA from lytic genes (K8 or ORF50) exceeded that of ORF73 when adjusted for total RNA recovered, though in two samples the amount of ORF73 mRNA exceeded the amount of ORF50 mRNA. The quantity of HHV-8 mRNA detected was highly correlated within samples (K8 and ORF50 Spearman coefficient $(\mathrm{Sp})=0.92$; $\mathrm{K} 8$ and ORF73 Sp=0.78; ORF50 and ORF73 Sp=0.84). Tumors of nodular morphotype had a lower proportion of lytic genes detected compared to macular morphotype (K8/ ORF73 $\mathrm{p}=0.04$; ORF50/ORF73 $\mathrm{p}=0.07$ ). The quantity of $\mathrm{K} 8$, ORF50, and ORF73 mRNA in KS biopsies was positively associated with the detection of oral HHV-8 (K8 $\mathrm{p}=0.003$; ORF50 $\mathrm{p}<0.001$; ORF73 $\mathrm{p}=0.002$ ). The quantity of lytic K8 and ORF50 mRNA, but not latent ORF73 mRNA, was also positively associated with the quantity of HHV-8 detected in saliva ( $\mathrm{K} 8 \mathrm{p}=0.06$; ORF50 $\mathrm{p}=0.06$ ).

\section{Conclusions}

KS tumors in our cohort express a preponderance of lytic HHV-8 gene products. The quantity of lytic HHV8 mRNA detected in KS tumors is associated with tumor morphotype and the detection of replicating HHV-8 in the oropharynx. Quantification of HHV-8 mRNA from KS tissue may provide insight into the pathophysiology of KS and could help predict disease progression and response to treatment.

\section{Acknowledgements}

This article has been published as part of Infectious Agents and Cancer Volume 5 Supplement 1, 2010: Proceedings of the $12^{\text {th }}$ International
'Department of Medicine, University of Washington, Seattle, WA, USA

Full list of author information is available at the end of the article 
Conference on Malignancies in AIDS and Other Acquired Immunodeficiencies (ICMAOI). The full contents of the supplement are available online at http://www.biomedcentral.com/1750-9378/5?issue=S1.

\section{Author details}

'Department of Medicine, University of Washington, Seattle, WA, USA. ${ }^{2}$ Department of Laboratory Medicine, University of Washington, Seattle, WA, USA. ${ }^{3}$ Department of Epidemiology, University of Washington, Seattle, WA, USA. ${ }^{4}$ Department of Global Health, University of Washington, Seattle, WA, USA. ${ }^{5}$ accine and Infectious Disease Institute, Fred Hutchinson Cancer Research Center, Seattle, WA, USA. ${ }^{6}$ Uganda Cancer Institute, Kampala, Uganda. ${ }^{7}$ Makerere University, College of Health Sciences, Kampala, Uganda.

Published: 11 October 2010

doi:10.1186/1750-9378-5-S1-A11

Cite this article as: Phipps et al:: Characterization of lytic human herpesvirus-8 gene expression in Kaposi sarcoma tumor tissue and its clinical correlates. Infectious Agents and Cancer 2010 5(Suppl 1):A11.

\section{Submit your next manuscript to BioMed Central} and take full advantage of:

- Convenient online submission

- Thorough peer review

- No space constraints or color figure charges

- Immediate publication on acceptance

- Inclusion in PubMed, CAS, Scopus and Google Scholar

- Research which is freely available for redistribution

Submit your manuscript at www.biomedcentral.com/submit 